\title{
Fossil crinoids from the basal West Point Formation (Silurian), southeastern Gaspé Peninsula, Québec, eastern Canada
}

\author{
Stephen K. DonOvan ${ }^{1^{*}}$ AND David G. KeIghleY ${ }^{2}$ \\ 1. Naturalis Biodiversity Center, Postbus 9517, 2300 RA Leiden, The Netherlands \\ 2. Department of Earth Sciences, University of New Brunswick, Fredericton, New Brunswick E3B 5A3, Canada \\ ${ }^{\star}$ Corresponding author $<$ steve.donovan@naturalis.nl $>$
}

Date received: 21 April 2016 g Date accepted: 20 May 2016

\begin{abstract}
Silurian strata of Atlantic Canada and southern Québec locally preserve common fossil crinoids, albeit mostly as disarticulated remains. New crinoids from the Chaleurs Group, West Point Formation (Ludlow to Pridoli?; Upper Silurian) of the Gaspé Peninsula include Iocrinus? maennili (Yeltysheva) (otherwise known from the Katian of Estonia), Bystrowicrinus (col.) depressus sp. nov. and Cyclocyclicus (col.) sp. aff. C. (col.) echinus Donovan. On the basis of both its gross morphology and stratigraphic position, Iocrinus? maennili is unlikely to be an iocrinid disparid, a family that became extinct at the end of the Ordovician. The trivial name has hitherto been erroneously spelled as männili, mannili and mjannili. Most specimens of the common Bystrowicrinus (col.) depressus appear cyclocyclic because the pentastellate lumen occurs in a deeply sunken claustrum that is commonly occluded by sediment; clean specimens are highly distinctive. Cyclocyclicus (col.) sp. aff. C. (col.) echinus is similar to a species known from the Katian of North Wales. Taken together, this assemblage is more reminiscent of Katian strata (Upper Ordovician). This is problematic given the current mapping of the outcrop as West Point Formation (Upper Silurian), suggesting further stratigraphic studies in the area are required.
\end{abstract}

\begin{abstract}
RÉSUMÉ
Les strates du Silurien au Canada atlantique et dans le sud du Québec renferment à divers endroits des fossiles de crinoïdes communs, bien qu'il s'agisse de vestiges morcelés. Parmi les nouveaux crinoïdes de la formation de West Point du groupe de Chaleurs (du Ludlow au Pridoli?; Silurien supérieur) de la péninsule de Gaspé, on compte Iocrinus? maennili (Yeltysheva) [observé par ailleurs dans l'étage Katien de l'Estonie], Bystrowicrinus (col.) depressus sp. nov. et Cyclocyclicus (col.) sp. aff. C. (col.) echinus Donovan. D’après sa morphologie générale et sa position stratigraphique, il est peu probable qu'Iocrinus? maennili fasse partie de la famille Iocrinidae (ordre Disparida), une famille disparue à la fin de l'Ordovicien. Son nom commun a été jusqu'à présent épelé incorrectement männili, mannili ou mjannili. La plupart des spécimens de Bystrowicrinus (col.) depressus commun ont un aspect cyclocyclique, car le lumen pentaétoilé se trouve dans un claustrum très profond généralement obstrué par des sédiments; les spécimens libres de sédiments ont un aspect très distinctif. Cyclocyclicus (col.) sp. aff. C. (col.) echinus est semblable à une espèce présente dans létage Katien du Pays de Galles nordique. Dans son ensemble, cet assemblage fait davantage penser à l'étage Katien (Ordovicien supérieur). C'est un problème, puisque la cartographie actuelle de l'affleurement montre celuici comme faisant partie de la formation de West Point (Silurien supérieur), ce qui laisse supposer que d’autres études stratigraphiques devront être menées dans la région.
\end{abstract}

[Traduit par la redaction] 


\section{INTRODUCTION}

Crinoids (= sea lilies; phylum Echinodermata) have a fossil record that extends back to the Early Ordovician (Guensburg and Sprinkle 2003). However, this record is strongly controlled by the taphonomy of the internal skeleton, which is mostly held together by soft tissue. As with other echinoderms, the skeleton consists of numerous calcite plates, or ossicles, that only rarely interlock (Donovan 1991) and so only in extremely rare instances are large parts of the skeleton preserved intact (e.g., Donovan and Pickerill 1995a). Mostly, the tissues decompose after death, individual plates disarticulate and the hard parts are scattered or destroyed by various sedimentological processes. So, although crinoid remains are abundant in sedimentary rocks, particularly in the supra-Cambrian Paleozoic, preservation is usually as disarticulated ossicles, a factor that makes classification problematic.

Silurian strata of Atlantic Canada and southern Québec (Fig. 1A) locally preserve common crinoid fossils that record the development of the Middle Paleozoic Crinoid Evolutionary Fauna, following the end-Ordovician mass extinctions (Baumiller 1993; Ausich and Deline 2012). Despite this, and most likely because material is usually of disarticulated columnals, only occasionally have crinoid fossils been classified from the region (mainly from Anticosti Island, Québec), and utilized to aid biostratigraphic, paleogeographic and paleoecologic studies (Billings 1857, 1859, 1866; Springer 1928; Kirk 1933; Northrop 1939; Bolton 1972, 1981; Ausich 1978, 2010; Donovan and Pickerill 1995a, b; Ausich and Copper 2010; Ausich and Deline 2012; Donovan and Miller 2014). Most recently, Donovan and Keighley (2015) described material from an outcrop of the La Vieille Formation (originally part of the Chaleurs Group; Lavoie et al. 1992) in northeastern New Brunswick. The present contribution documents further studies of the mostly disarticulated crinoid fauna from the type section of the Chaleurs Group, across Chaleur Bay, on the Gaspé Peninsula of Québec (Fig. 1). Specifically, the new collection is from an outcrop mapped as the West Point Formation, a unit that previously has yielded crotalocrinitid cladid crinoids of the genus Syndetocrinus Kirk 1933 (Northrop 1939).

\section{LOCATION AND STRATIGRAPHY}

An apparently continuous succession of Lower Silurian to Lower Devonian strata outcrops on the Gaspé Peninsula. At Port Daniel, the Chaleurs Group is more than $1 \mathrm{~km}$ thick and sits unconformably on Middle Ordovician flysch deposits of the basal Mictaw Group (Bourque 1975; Bourque et al. 2001; Énergie et Ressources naturelles Québec 2016). Two major carbonate intervals occur in the succession (Figs 1, 2); the lower interval is assigned to the La Vieille Formation and the upper to the West Point Formation (or Crotalocrinus limestones; Bourque 1975). The two carbonate intervals are interpreted to represent various platformal (peritidal, reefal and subtidal) facies deposited during the culmination of two separate regional, tectonic- and eustatic-influenced marine regressions (Bourque et al. 2001). Overlying the fine-grained siliciclastics of the Gascons Formation, the West Point Formation is divided into several members (Bourque et al. 1986). The basal fine-grained siliciclastics and carbonate mudrocks (Bouleaux Member) are overlain successively by red-grey, mound-shaped, algal-spongestromatactis limestone and grey, massive, pelletalbioclastic-laminite limestone (Gros Morbe and Anse à la Barbe members, repectively). Collectively they form part of a shallowing-upward, 'lower reef complex', with a brecciated limestone representing a laterally offshore equivalent (Anse à la Loutre Member of the Indian Point Formation). The lower reef complex in turn is overlain by a crinoidal 'middle bank complex' (Anse McInnis Member), from which Syndetocrinus was recovered previously, and an 'upper reef complex' (Sandy Cove and Colline Daniel members; Fig. 1B). It is from the basal Bouleaux Member that the current material has been retrieved. Most material has been recovered from argillaceous limestone outcrop near the crest of a hill on the north side of route 132. Additional fossils in the same beds include brachiopods, bryozoans and trilobites.

Biostratigraphically, the La Vieille Formation is constrained to the late Llandovery or early Wenlock by brachiopods, conodonts and chitinozoa (Nowlan 1983; Asselin et al. 1989). Based on graptolites, the Gascons Formation is latest Wenlock (Lenz 1975); corals from the type West Point Formation indicate a Ludlow to possibly

Figure 1. (following page) (A) General location map of the outcrop of the Chaleurs Group in southeastern Quebec and of equivalent (formerly Chaleurs Group) strata in northern New Brunswick (modified from Donovan and Keighley 2015, fig. 1A). (B) Geological map of the Port Daniels area. The Lower Silurian of the Chaleurs Group comprises the basal Clemville Fm. (a), Weir Fm. (b), Anse Cascon Fm. (c), and Anse à Pierre Loiselle Fm. (d) that laterally interfingers with the La Vieille Fm. At this scale, the various members of the West Point Formation are included as part of either the 'lower reef complex' (Bouleux, Gros Morbe, Anse à la Barbe members = x), 'middle bank' (Anse McInnis Member = y) or 'upper reef complex' (Colline Daniel and Sandy Cove members $=\mathrm{z}$ ). Adapted from Bourque et al. (1986), Énergie et Ressources naturelles Québec (2016, online map). 


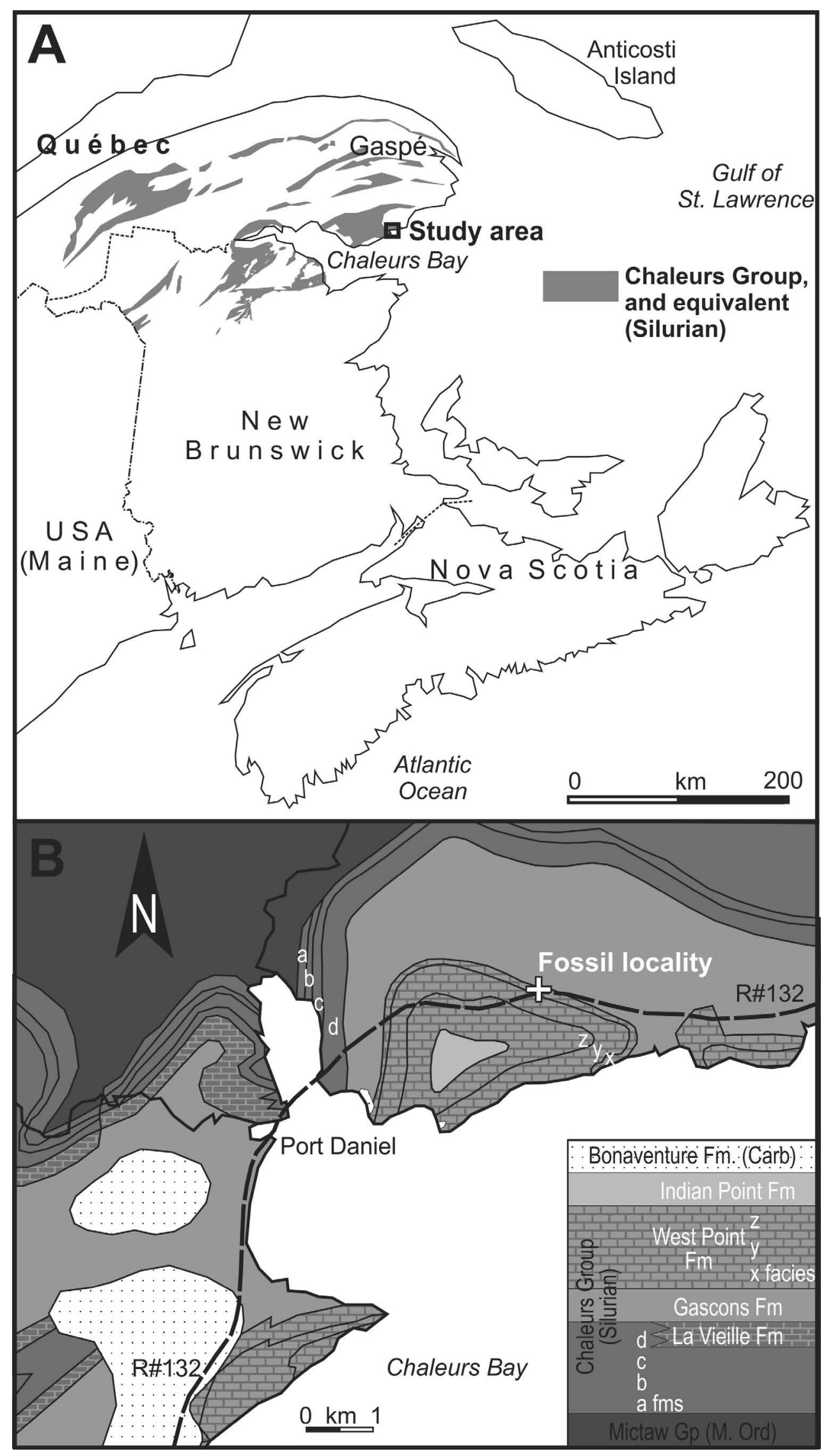


Pridoli age (Young and Noble 1990). In central and northern Gaspé, West Point Formation platformal carbonate deposition possibly persisted into the Devonian, but in the Port Daniel area sedimentation likely terminated in the latest Silurian with the development of the main Salinic unconformity (Bourque et al. 2001; Wilson et al. 2004). In contrast, south into New Brunswick, the Silurian succession contains up to three distinct unconformities related to both sea-level fall and orogeny (Salinic A-C hiatuses, Fig. 2).

\section{SYSTEMATIC PALAEONTOLOGY}

REMARKS: The crinoids described herein are known from disarticulated ossicles (columnals, brachials) or, at best, relatively short pluricolumnals (Figs 3, 4). Terminology of the crinoid endoskeleton follows Webster (1974), Ubaghs (1978), Moore et al. (1978a) and Donovan (1986). Our philosophy of open nomenclature follows Bengtson (1988). Specimens discussed herein are deposited in the Natural Science Department, New Brunswick Museum, Saint John (specimen numbers prefixed by NBMG).

Class Crinoidea J.S. Miller 1821

Subclass Disparida Moore and Laudon 1943

Order Myelodactylida Ausich 1998

Family Iocrinidae Moore and Laudon 1943

\section{Genus Iocrinus Hall 1866}

TYPE SPECIES: Heterocrinus (Iocrinus) polyxo Hall 1866, p. 5, pl. 1, figs. 1-4 (= Actinocrinus subcrassus Meek and Worthen 1865, p. 148), by monotypy, from the Ordovician (Champlainian to Cincinnatian) of Ohio, New York and Ontario (Moore et al. 1978b, p. T522; Webster 2016).

DIAGNOSIS: See Donovan et al. (2011, p. 526).

REMARKS: The specimens described herein are not Iocrinus sensu stricto; the family Iocrinidae is limited to the Ordovician (Eckert 1988). However, current nomenclatural procedure, detailed below, predicates that the systematic palaeontology is best presented under this genus. The material is morphologically very close to the form figured by Stukalina (1988, particularly pl. 7, figs 14-16) as Iocrinus? mjannili [sic] Yeltysheva, an Upper Ordovician columnal morphotaxon which is not, however, close to true Iocrinus (see the following for comparison: Kelly 1978; Donovan and Gale 1989; Donovan et al. 2011).

Although a new morphogenus needs to be erected, we did not have access to the type series of Iocrinus maennili, a factor that we considered precluded the possibility of establishing one herein with Iocrinus maennili as type. Although unsatisfactory, we did not wish to make a confused systematic situation more so.

RANGE: Ordovician: Champlainian to Cincinnatian of North America; Llanvirn of Wales; Arenig of Oman (Donovan et al. 2011, p. 527).

\section{Iocrinus? maennili (Yeltysheva 1979)}

(Figures 4A-C)

1986 Jocrinus? [sic] mjannili [sic] Yeltyschewa; Stukalina, p. 133 [caption], pl. 14, figs. 14-17.

1988 Iocrinus? mjannili [sic] Yeltyscheva; Stukalina, p. 60 [caption], pl. 7, figs 14-17.

1993 Iocrinus? mannili [sic] Yeltyscheva; Webster, p. 165.

2000 Ejmaacrinus mjannili [sic] (Yeltysheva); Stukalina, p. 179 [caption], pl. 5, figs 14-17 [nomen nudum?].

2016 Iocrinus? mannili [sic] Yeltyscheva; Webster, p. 2475.

MATERIAL: Two specimens on slab NBMG 20268 (Fig. $4 \mathrm{~A}-\mathrm{C})$.

DESCRIPTION: Articular facet pentagonal. Articulation symplectial; crenulae perpendicular to sides of facet and arrayed in a curved envelope on each side, shortest at the angles and longest in the center of each side. Areola planar, pentastellate in outline and extending into angles of column. Lumen central, circular, moderately broad. Pluricolumnal heteromorphic N212; latera planar except in angles of $\mathrm{N}$ and IIN where asymmetric nodes are lobe-like and oriented aborally(?). Nodals slightly higher than 1IN; 2IN much lower; symplectial articulation apparent in lateral view. The shorter pluricolumnal (Fig. 4A) has lower columnals and may be more proximal.

REMARKS: Iocrinus? maennili was originally described from the Upper Ordovician (Katian) Pirgu Stage (Fortey et al. 2000, fig. 34; Cooper and Sadler 2012) of the northwest East European Platform of Estonia (Stukalina 1988, p. 60; Webster 1993, p. 2475). Our report is thus an extension in both geography (to Laurentia) and stratigraphy (to Ludlow, late Silurian) for this taxon. The morphology of the articular facet and latera are so distinctive that we accept these extensions rather than postulating convergent evolution, although this is obviously an alternative explanation of such a disjunct distribution. Other morphotaxa which have some similarity to the specimens discussed herein include Pentagonocyclopa (col.) hughesi Donovan 1995 (pl. 18, figs $8,9)$ and the nomen nudum 'Pentagonycrinus ekkentros' (Briskeby 1981, p. 141, fig. 47, pl. 8, figs 8, 9); indeed, the 


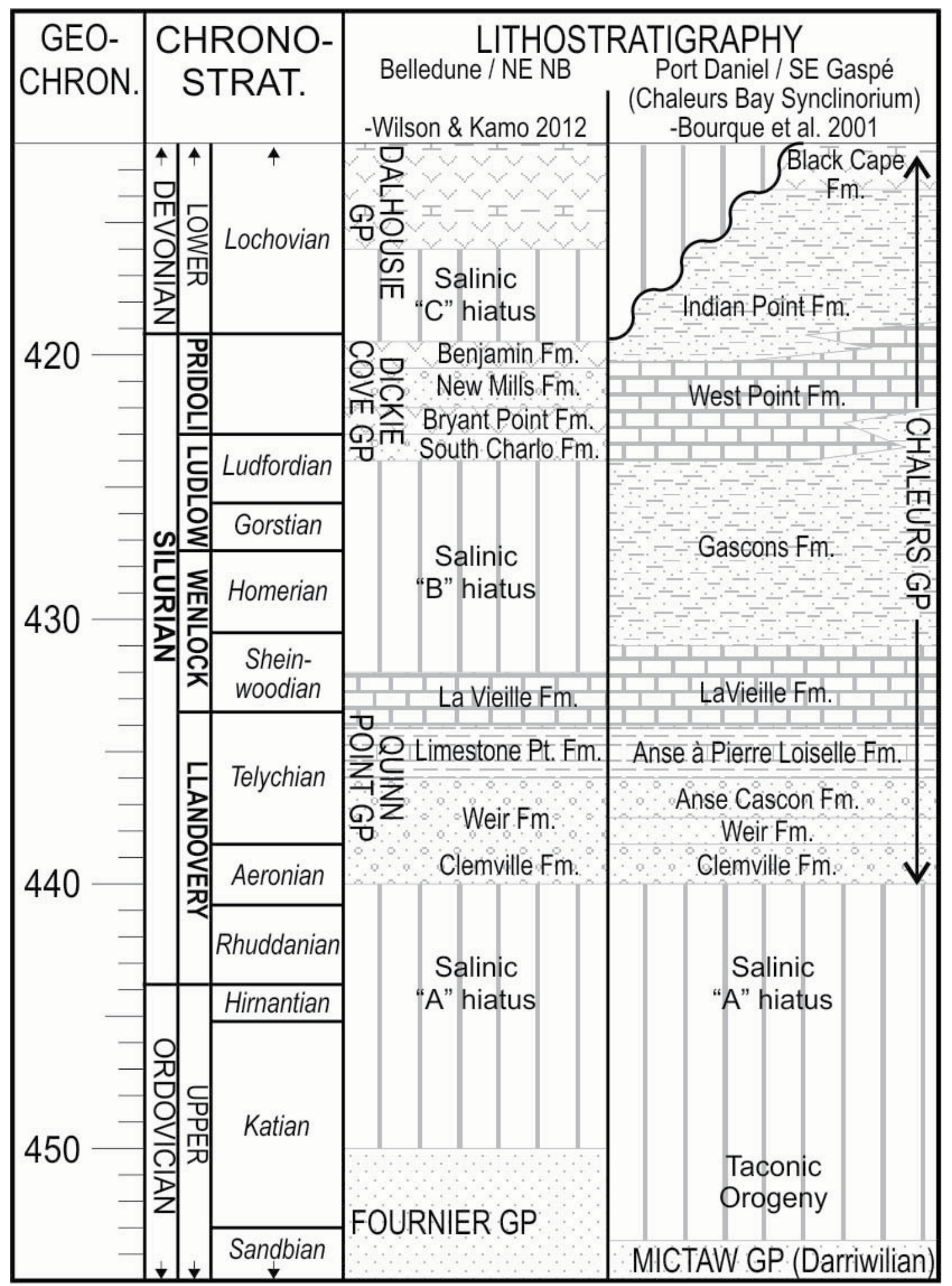

Figure 2. Lithostratigraphy, chronostratigraphy and geochronology of the Chaleurs Group in southeastern Québec (column at far right) and equivalent rocks (formerly assigned to the Chaleurs Group) in northern New Brunswick (second column from right). Lithostratigraphy is from Bourque et al. (2001), Fyffe et al. (2011) and Wilson and Kamo (2012); chronostratigraphic boundary dates are taken from Melchin et al. (2012). 


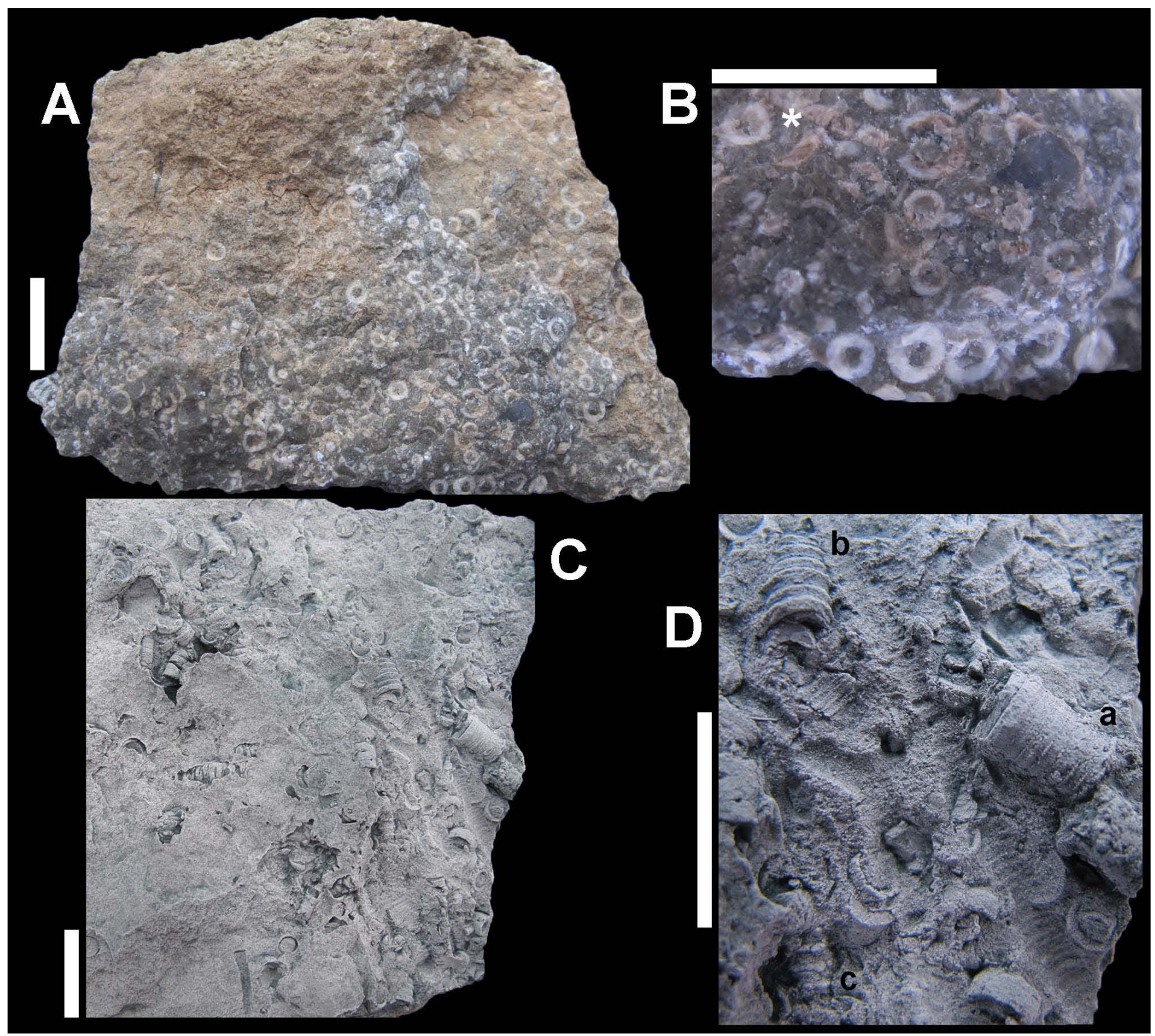

Figure 3. Fossil crinoids of the West Point Formation, Québec, eastern Canada. (A, B) NBMG 20265, Bystrowicrinus (col.) depressus sp. nov., bedding plane views of specimens preserved in transverse sections (i.e., pseudocyclocyclic preservation). (A) General view. (B) Enlargement of part of the lower right of (A); note columnal left of $\left(^{*}\right)$ shows imperfectly exposed pentastellate (= Bystrowicrinus) lumen. (C, D) NBMG 20266, bedding plane views. (C) General view. (D) Details from center right of (C). Specimens (a) and (b) are Bystrowicrinus (col.) depressus sp. nov., paratypes, morphology A and B, respectively. Specimen (c) is Cyclocyclicus (col.) sp. aff C. depressus Donovan. All scale bars represent $10 \mathrm{~mm}$. Specimens in (C) and (D) coated with ammonium chloride.

latter may be synonymous with Iocrinus? maennili.

A note on the trivial name of this taxon is well warranted. Iocrinus männili Yeltysheva 1979 (p. 95, pl. 2, fig. 1) was originally named with an umlaut on the 'a.' The use of an umlaut in the name of a taxon is not supported by the International Commission on Zoological Nomenclature (1999, article 32.5.2 on p. 40), as indicated in the following excerpts:

"32.5.2. A name published with a diacritic or other mark, ligature, apostrophe, or hyphen, or a 


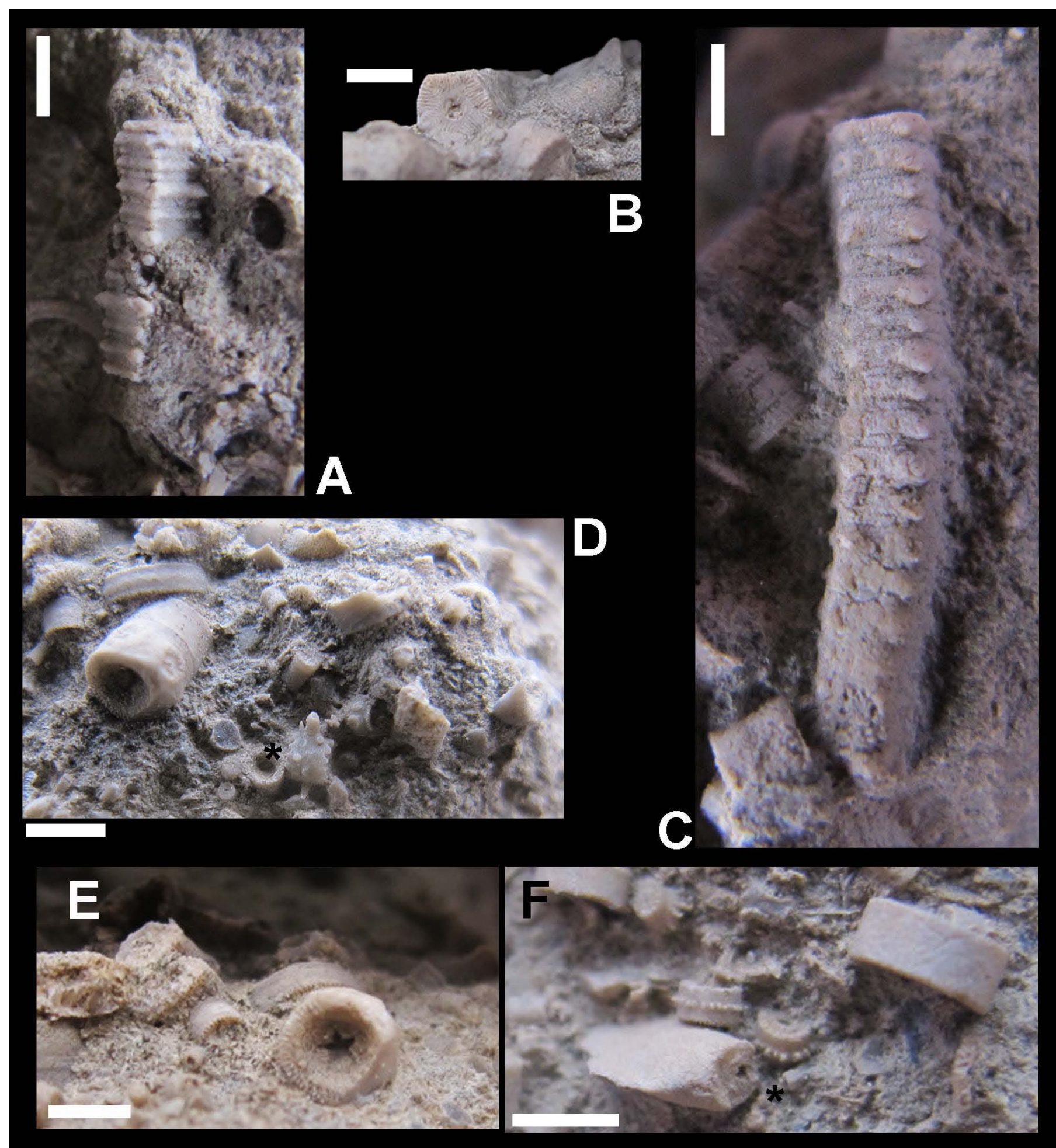

Figure 4. Fossil crinoids of the West Point Formation, Québec, eastern Canada. (A-C) Iocrinus? maennili (Yeltysheva), both on NBMG 20268. (A) NBMG 20268A, lateral view of small pluricolumnal. (B, C) NBMG 20268B. (B) Articular facet. (C) Lateral view of pluricolumnal; note swollen columnal angles, lobes all directed distally(?). (D) NBMG 20267, specimen to right of $\left.{ }^{*}\right)$ in the lower center is a columnal of Cyclocyclicus (col.) sp. aff. C. echinus Donovan; specimen left center is pluricolumnal of Bystrowicrinus (col.) depressus sp. nov., paratype (morphology A), with radice scars on nodal. (E) NBMG 20267, Bystrowicrinus (col.) depressus sp. nov., holotype, just right of lower center, articular facet. (F) NBMG 20267, possibly Bystrowicrinus (col.) depressus sp. nov., brachial $(*)$ showing bladed aboral surface and articular facet. Adjacent to this are two small Bystrowicrinus (col.) depressus morphology B columnals; a larger morphology A columnal is apparent in the upper right. All scale bars represent $2 \mathrm{~mm}$. No specimens coated. 
species-group name published as separate words of which any is an abbreviation, is to be corrected.

32.5.2.1. In the case of a diacritic or other mark, the mark concerned is deleted, except that in a name published before 1985 and based upon a German word, the umlaut sign is deleted from a vowel and the letter " $e$ " is to be inserted after that vowel (if there is any doubt that the name is based upon a German word, it is to be so treated).

Examples. nuñezi is corrected to nunezi, and mjøbergi to mjobergi, but mülleri (published before 1985) is corrected to muelleri."

Previous spellings of the trivial name (see synonymy, above), variously as männili, mannili and mjannili, are all, thus, erroneous. The correct name for this taxon is Iocrinus? maennili, adopted herein.

Stukalina (2000) placed this species in what appears to be a new genus, Ejmaacrinus. However, this genus was not formally diagnosed therein and we have been unable to determine where it was described, if anywhere. For example, Ejmaacrinus was not listed by Webster (2016). A web search for this generic name <Ejmaacrinus+crinoid> only achieved hits in online catalogues of Estonian material listed as Ejmaacrinus mjannili (such as Anon 2012-2013). We conclude that Ejmaacrinus is a nomen nudum; however, in case our determination is erroneous, we have decided, for now, not to erect a new genus for this species.

\section{Incertae ordinis}

REMARKS: Attempts have been made in the past to accommodate disarticulated pluricolumnals and columnals within the standard scheme of crinoid classification, with some successes, but many failures. It is conservative to emphasize the problems of such designations and group those nominal disarticulated columnals given morphogeneric names together as incerti ordinis. Columnal morphogenera are listed alphabetically. For explanation of the use of '(col.)' in association with columnal morphotaxa, see Donovan (1986, pp. 17-18).

Morphogenus Bystrowicrinus (col.) Yeltysheva in Yeltysheva and Stukalina 1963

TYPE SPECIES: Pentagonopentagonalis quinquelobatus Yeltysheva 1955, p. 43, pl. 23, figs. 4, 5, pl. 37, figs 5, 6; from the Middle Ordovician of the Siberian Platform (Donovan 1995, p. 128).
DIAGNOSIS: Columnals holomeric, circular or pentagonal in outline; axial canal pentastellate, narrow centrally, but with five equally-spaced lumen rays, pointing towards angles of columnal (if present); areola present or absent; articulation symplectial. (After Donovan 1995, p. 128.)

REMARKS: See Donovan (1995, p. 128).

RANGE: Ordovician (Darriwilian-Katian) and Silurian (Llandovery-Wenlock) of Russia; Ordovician (Katian) of Latvia and Estonia; Devonian (Emsian) of Czech Republic (Webster 2016, p. 2292); Upper Ordovician and Lower Devonian of the British Isles (Donovan 1995, 2012); Silurian (Ludlow) of eastern Canada (herein).

\section{Bystrowicrinus (col.) depressus sp. nov.}

(Figures 3, 4D-F)

TYPE MATERIAL: Holotype: NBMG 20267 (Fig. 4E). Paratypes, NBMG 20265 (Fig. 3A, B), 20266 (Fig. 3C, D), 20267 (Fig. 4D).

OTHER MATERIAL: Multiple, unfigured specimens of this species occur on NBMG 20265-20269.

DIAGNOSIS: Columnals circular in outline, pseudocyclocyclic, lumen central and pentastellate, and perforating a thin, depressed claustrum at mid-height, well below the radial symplectial articulation. Heteromorphic, N212(?) to N3231323. Latera either planar or with $\mathrm{N}$ and IIN with a band of low tubercles at mid-height. Brachials elongate with an aboral flange.

DESCRIPTION: Columnals circular in section. Articulation radial symplectial, marginal, no more than a third of the diameter of the columnal. Commonly appear cyclocyclic with 'lumen' more than $50 \%$ of columnal diameter (Fig. 3A, B), wider in what are probably more proximal columnals. However, rare well-preserved specimens have a strongly depressed, thin central claustrum with a central pentastellate lumen (Fig. 4E).

Pluricolumnals of two principal morphologies, called $\mathrm{A}$ and $\mathrm{B}$ herein (Fig. 3C, D). Morphology A commonly heteromorphic, N3231323. Nodals highest with gently convex latera; internodals of regularly differing heights, latera planar to gently convex. Rare pluricolumnals bear circular radice scars at mid-height (Fig. 4D, left); articulation of radice scar symplectial, comprising about 16 short, robust crenulae per facet; central small, rounded lumen; and a slightly raised circumference. First radice ossicle low.

Pluricolumnal morphology $\mathrm{B}$ also heteromorphic, at least N212, columnals differentiated on similar criteria to morphology A. Pluricolumnal B differentiated by having a 
finely tuberculate ridge at mid-height of the gently convex latera of nodals $(\mathrm{N})$ and priminternodals (1IN).

REMARKS: The unusual feature of this taxon is the thin claustrum bearing a central, pentastellate lumen. Most columnals appear to be cyclocyclic because the depressed jugulum is infilled by sedimentary rock; even a thin veneer of limestone is sufficient to mask the axial canal or appears so in section (Fig. 3A, B). Only rare specimens have a claustrum exposing the true lumen (Figs 3B, 4E). Analogous comments have been applied to other columnal morphotaxa (see, for example, Donovan and Keighley 2015). Some pluricolumnals of this taxon are encrusted by bryozoans on NBMG 20267.

Brachials (Fig. 4F) associated with these specimens may or may not be conspecific; Bystrowicrinus (col.) depressus is the commonest of the three columnal morphotaxa described herein, yet it is possible that the brachials may represent a fourth taxon. The brachials are robust, elliptical in section and elongate (Fig. 4F). The adoral groove is a small, squaresided U; the axial canal is small and rounded, situated just below adoral groove. Articulation is synostosial(?). Most unusually, the aboral surface has a blade-like, longitudinal flange.

\section{Morphogenus Cyclocyclicus (col.) Yeltysheva 1955}

TYPE SPECIES: Cyclocyclicus tenuis Yeltysheva 1955, pp. 46, 47, pl. 54, fig. 6, by monotypy, from the Lower Silurian (Llandovery) of the Siberian Platform (Yeltysheva 1960, p. 25).

DIAGNOSIS: See Fearnhead and Donovan (2007, p. 340).

REMARKS: Cyclocyclicus (col.) is a polyphyletic morphogenus for the common, nondescript circular columnals with circular lumina that are found in many Paleozoic pelmatozoan clades (Donovan et al. 2012, p. 221).

RANGE: Ordovician to Permian, worldwide (Jeffords 1978, p. T933; Donovan 1989, p. 103).

\section{Cyclocyclicus (col.) sp. aff. C. (col.) echinus Donovan 1989} (Figures. 3D, 4D)

MATERIAL, LOCALITY AND HORIZON: Specimens on slabs NBMG 20266, 20267.

DESCRIPTION: (Based mainly on a well-preserved specimen on NBMG 20267.) Small, cyclocyclic pluricolumnal with long spines (or pseudocirri?) on nodals (Figs. 3D, $4 \mathrm{D})$, three apparent in about $180^{\circ}$ of latus. Articulation symplectial, coarse. Areola narrow; small, central, circular lumen. Columnals slightly higher than wide. Some conspecific columnals have a ridge of pointed tubercles on the latus at mid-height. Heteromorphic, perhaps N212.

REMARKS: Cyclocyclicus (col.) echinus sensu stricto (Donovan 1989, pp. 104-105, pl. 11, fig. 6) is from high in the Upper Ordovician (Katian; Rawtheyan) of Keisley, Cumbria, northwestern England. Its diagnosis states: "A morphospecies of [small] cyclocyclic columnal, with the axial canal constricted by a circular claustrum, no areola, a crenularium of radial crenulae, some bifurcating, and a latus that is planar and sculptured by numerous short, [slightly] curved spines in nodals. Column heteromorphic." The differences between the type material and the specimens discussed herein involve mainly the features of the articular facet (areola) and axial canal (claustrum), but such variations might occur along the length of the column of a single species or even individual. Rather than encumber the literature with a new name, we choose to affiliate the present distinctive columnals within an existing taxon until more complete specimens become available.

\section{DISCUSSION}

The only contentious issue that is raised by our analysis is the age of the deposit. On the basis of the crinoid fauna, it seems more likely to be Katian (Late Ordovician) than Ludlow or Pridoli (Late Silurian). Iocrinus? maennili is otherwise limited to the Katian of Estonia; Bystrowicrinus (col.) spp. are better known from the Katian than Silurian (Donovan 1995; Webster 2016, p. 2292); and Cyclocyclicus (col.) echinus sensu stricto was described from the Katian of northwestern England.

Crinoids are not widely appreciated for their biostratigraphic value and the data from crinoid columnals described herein is likely to be regarded as no more than a curiosity. However, individual specimens are well preserved and not individually reworked. Therefore, if the suggested Ordovician date is to stand, we would have to speculate that the outcrop forms an allochthonous block of Upper Ordovician rock not otherwise preserved in the region, or evidence of a small fault slice or sliver of Upper Ordovician strata that has hitherto escaped unnoticed. We appreciate that both are unlikely. Expert examination of other shelly elements from this site, such as brachiopods, trilobites and conodonts, should help to clarify this issue. Although Silurian Syndetocrinus Kirk is known from the West Point Formation, it was not found at the locality considered herein. 


\section{ACKNOWLEDGEMENTS}

SKD gratefully acknowledges the award of a G.F. Matthew Research Grant for 2013 by the New Brunswick Museum, which facilitated this research in May 2014. Naturalis Biodiversity Center, Leiden, provided further support and further facilitated a research visit to the New Brunswick Museum in May 2014. Special thanks to Gary D. Webster (Washington State University, Pullman) for loan of Russian monographs to S.K.D. Incisive reviews by William I. Ausich (The Ohio State University, Columbus) and David N. Lewis (Natural History Museum, London), along with editorial comments by Rob Fensome, greatly improved the final draft.

\section{REFERENCES}

Anon. 2012-2013. Crinoids: Class Crinoidea Miller, 1821. Paleodiversity in Baltoscandia. URL <http://fossiilid. info/341> May, 2016.

Asselin, E., Achab, A., and Bourque, P.A. 1989. Chitinozoaires du Silurien inférieur dans la région de la baie des Chaleurs en Gaspésie, Québec, Canada. Canadian Journal of Earth Sciences, 26, pp. 2435-2449. http://dx.doi.org/10.1139/ e89-208

Ausich, W.I. 1978. Pisocrinus from California, Nevada, Utah and Gaspé Peninsula. Journal of Paleontology, 52, pp. 487-491.

Ausich, W.I. 1998. Phylogeny of Arenig to Caradoc crinoids (phylum Echinodermata) and suprageneric classification of the Crinoidea. University of Kansas Paleontological Contributions, new series, 9, pp. 1-36.

Ausich, W.I. 2010. Post-hoc sampling analysis of crinoid collections from Anticosti Island, Quebec, Canada. Memoir of the Association of Australasian Palaeontologists, 39, pp. 19-25.

Ausich, W.I. and Copper, P. 2010. The Crinoidea of Anticosti Island, Quebec (Late Ordovician to Early Silurian). Palaeontographica Canadiana, 29, $157 \mathrm{p}$.

Ausich, W.I. and Deline, B. 2012. Macroevolutionary transition in crinoids following the late Ordovician extinction event (Ordovician to Early Silurian). Palaeogeography, Palaeoclimatology, Palaeoecology, 361/362, pp. 38-48. http://dx.doi.org/10.1016/j.palaeo. 2012.07.022

Baumiller, T.K. 1993. Survivorship analysis of Paleozoic Crinoidea: effect of filter morphology on evolutionary rates. Paleobiology, 19, pp. 304-321. http://dx.doi. org/10.1017/S0094837300000294

Bengtson, P. 1988. Open nomenclature. Palaeontology, 31, pp. 223-227.

Billings, E. 1857. New species of fossils from Silurian rocks of Canada. Geological Survey of Canada, Report of Progress 1853-1856. Report for the year 1856, pp. 247-345.
Billings, E. 1859. On the Crinoideae of the Lower Silurian rocks of Canada. Canadian Organic Remains, Decade 4, Geological Survey of Canada, $72 \mathrm{p}$.

Billings, E. 1866. Catalogue of the Lower Silurian fossils of the island of Anticosti, with descriptions of some of the species. Geological Survey of Canada, $99 \mathrm{p}$.

Bolton T.E. 1972. Geologic map and notes on the Ordovician and Silurian litho- and biostratigraphy, Anticosti Island, Québec. Geological Survey of Canada Paper 71-19, 45 p.

Bolton, T.E. 1981. Ordovician and Silurian biostratigraphy, Anticosti Island, Québec. In International Union of Geological Sciences, Subcommission on Silurian Stratigraphy, Ordovician-Silurian Boundary Working Group, Field Meeting, Anticosti-Gaspé, Québec, 1981, Volume 2: Stratigraphy and Paleontology. Edited by P.J. Lespérance, pp. 41-59.

Bourque, P-A. 1975. Lithostratigraphic framework and unified nomenclature for Silurian and basal Devonian rocks in eastern Gaspé Peninsula, Québec. Canadian Journal of Earth Sciences, 12, pp. 858-872. http://dx.doi. org/10.1139/e75-075

Bourque, P-A., Amyot, G., Desrochers, A., Gignac, H., Gosselin, C., Lachambre, G. and Laliberté, J.Y. 1986. Silurian and Lower Devonian reef and carbonate complexes of the Gaspé Basin, Québec - a summary. Bulletin of Canadian Petroleum Geology, 34, pp. 452-489.

Bourque, P-A., Malo, M. and Kirkwood, D. 2001.Stratigraphy, tectono-sedimentary evolution and paleogeography of the post-Taconian - pre-Carboniferous Gaspé Belt: an overview. Bulletin of Canadian Petroleum Geology, 40, pp. 186-201. http://dx.doi.org/10.2113/49.2.186

Briskeby, P.I. 1981. Klassifikasjon av krinoidstilker fra den over-Ordoviciske Kalvsjøformaasjonen på Hadeland. Unpublished thesis, Paleontologisk Museum, Universitetet i Oslo, $170 \mathrm{p}$.

Cooper, R.A. and Sadler, P.M. 2012. The Ordovician Period. Chapter 20. In The geological time scale, 2012. Volume 2, Edited by F. Gradstein, J. Ogg, M. Schmitz, M. and G. Ogg. Elsevier, pp. 489-523. http://dx.doi.org/10.1016/ b978-0-444-59425-9.00020-2

Donovan, S.K. 1986. Pelmatozoan columnals from the Ordovician of the British Isles. Part 1. Monographs of the Palaeontographical Society, London, 138 (no. 568), pp. $1-68$.

Donovan, S.K. 1989. Pelmatozoan columnals from the Ordovician of the British Isles. Part 2. Monographs of the Palaeontographical Society, London, 142 (no. 580), pp. 69-114.

Donovan, S.K. 1991. The taphonomy of echinoderms: calcareous multi-element skeletons in the marine environment. In The processes of fossilization. Edited by S.K. Donovan. Belhaven Press, London, pp. 241-269.

Donovan, S.K. 1995. Pelmatozoan columnals from the Ordovician of the British Isles. Part 3. Monographs of the 
Palaeontographical Society, London, 149 (no. 597), pp. 115-193.

Donovan, S.K. 2012. Notes on Lower Devonian crinoids in the collections of the British Geological Survey, Keyworth. Proceedings of the Yorkshire Geological Society, 59, pp. 115-120. http://dx.doi.org/10.1144/pygs2012-318

Donovan, S.K. and Gale, A.S. 1989. Iocrinus in the Ordovician of England and Wales. Palaeontology, 32, pp. 313-323.

Donovan, S.K. and Keighley, D.G. 2015. A 'British' Silurian crinoid from Quinn Point, New Brunswick, eastern Canada. Proceedings of the Geologists' Association, 126, pp. 226-231.

Donovan, S.K. and Miller, R.F. 2014. The camerate crinoid Scyphocrinites Zenker in the Upper Silurian or Lower Devonian of New Brunswick, Canada. Atlantic Geology, 50, pp. 290-296. http://dx.doi.org/10.4138/ atlgeol.2014.014

Donovan, S.K. and Pickerill, R.K. 1995a. Crinoid columns preserved in life position in the Silurian Arisaig Group of Nova Scotia, Canada. Palaios, 10, pp. 362-370. http:// dx.doi.org/10.2307/3515161

Donovan, S.K. and Pickerill, R.K. 1995b. A camerate crinoid from the Upper Silurian (Ludlow) Moydart Formation of Nova Scotia, Canada. Atlantic Geology, 31, pp. 81-86. http://dx.doi.org/10.4138/2099

Donovan, S.K., Miller, C.G., Sansom, I.J., Howard, A.P., and Schreurs, J. 2011. A Laurentian Iocrinus Hall (Crinoidea, Disparida) in the Dapingian or Darriwilian (Middle Ordovician, Arenig) of Oman. Palaeontology, 54, pp. 525533. http://dx.doi.org/10.1111/j.1475-4983.2011.01042.x

Donovan, S.K., Widdison, R.E., Lewis, D.N., and Fearnhead, F.E. 2012. The British Silurian Crinoidea. Part 3, addendum to parts 1 and 2, Camerata and columnals. Monograph of the Palaeontographical Society, London, 166 (638), pp. 135-259.

Eckert, J.D. 1988. Late Ordovician extinction of North American and British crinoids. Lethaia, 21, pp. 147-167. http://dx.doi.org/10.1111/j.1502-3931.1988.tb00805.x

Énergie et Ressources naturelles Québec 2016. URL <http:// sigeom.mines.gouv.qc.ca>.March, 2016.

Fearnhead, F.E. and Donovan, S.K. 2007. A robust crinoid from the Llandovery (Lower Silurian) of Norbury, Shropshire: systematics, palaeoecology and taphonomy. Proceedings of the Geologists' Association, 118, pp. 339345.

Fortey, R.A., Harper, D.A.T., Ingham, J.K., Owen, A.W., Parkes, M.A., Rushton, A.W.A., and Woodcock, N.H. 2000. A revised correlation of Ordovician rocks in the British Isles. Geological Society, Special Report, 24, 83 p.

Fyffe, L.R., Johnson, S.C., and van Staal, C.R. 2011. A review of Proterozoic to early Paleozoic lithotectonic terranes in the northeastern Appalachian orogen of New Brunswick, Canada, and their tectonic evolution during Penobscot,
Taconic, Salinic, and Acadian orogenesis. Atlantic Geology, 47, pp. 211-248. http://dx.doi.org/10.4138/ atlgeol.2011.010

Guensburg, T.E. and Sprinkle, J. 2003. The oldest known crinoids (Early Ordovician, Utah) and a new crinoid plate homology system. Bulletin of American Paleontology, 364 , pp. 1-43.

Hall, J. 1866. Descriptions of new species of Crinoidea and other fossils from the Lower Silurian strata of the age of the Hudson-River Group and Trenton limestones. Privately published, Albany, New York, 17 p. [Not seen.]

International Commission on Zoological Nomenclature. 1999. International Code of Zoological Nomenclature. Fourth edition. International Trust for Zoological Nomenclature, London, $\mathrm{xxix}+306 \mathrm{p}$.

Jeffords, R.M. 1978. Dissociated crinoid skeletal elements. In Treatise on invertebrate paleontology. Part $\mathrm{T}$. Echinodermata 2(3). Edited by R.C. Moore and C. Teichert. Geological Society of America and University of Kansas, Boulder and Lawrence, pp. T928-T937.

Kelly, S.M. 1978. Functional morphology and evolution of Iocrinus, an Ordovician disparid inadunate crinoid. Unpublished MS thesis, Indiana University, vi $+79 \mathrm{p}$.

Kirk, E. 1933. Syndetocrinus, a new crinoid genus from the Silurian of Canada. American Journal of Science, 26, pp. 344-354. http://dx.doi.org/10.2475/ajs.s5-26.153.344

Lavoie, D., Bourque, P.-A. and Hrroux, Y. 1992. Early Silurian carbonate platform in the Appalachian orogenic belt: the Sayabec-La Vieille Formation of the Gaspé-Matapédia Basin, Québec. Canadian Journal of Earth Sciences, 29, pp. 704-719. http://dx.doi.org/10.1139/e92-061

Lenz, A. 1975. Silurian graptolites from eastern Gaspé, Québec. Canadian Journal of Earth Sciences, 12, pp. 7789. http://dx.doi.org/10.1139/e75-009

Meek, F.B. and Worthen, A.H. 1865. Description of new species of Crinoidea, \&c., from the Palaeozoic rocks of Illinois and some of the adjoining states. Proceedings of the Academy of Natural Sciences of Philadelphia, 17, pp. 143-155.

Melchin, M.J., Sadler, P.M., and Cramer, B.D. 2012. The Silurian Period. Chapter 21. In The geological time scale, 2012. Volume 2, Edited by F. Gradstein, J. Ogg, M. Schmitz, M. and G. Ogg. Elsevier, pp. 525-558. http:// dx.doi.org/10.1016/b978-0-444-59425-9.00021-4

Miller, J.S. 1821. A natural history of the Crinoidea or lilyshaped animals, with observation on the genera Asteria, Euryale, Comatula and Marsupites. C. Frost, Bristol, $150 \mathrm{p}$.

Moore, R.C. and Laudon, L.R. 1943. Evolution and classification of Paleozoic crinoids. Geological Society of America Special Paper, 46, 153 p. http://dx.doi. org/10.1130/spe46-p1

Moore, R.C. with additions by Ubaghs, G., Rasmussen, H.W., Breimer, A., and Lane, N.G. 1978a. Glossary of crinoid morphological terms. In Treatise on invertebrate 
paleontology. Part T. Echinodermata 2(1). Edited by R.C. Moore and C. Teichert. Geological Society of America and University of Kansas, Boulder and Lawrence, pp. T229, T231, T233-T242.

Moore, R.C., Lane, N.G., Strimple, H.L., and Sprinkle, J. 1978b. Order Disparida Moore \& Laudon, 1943. In Treatise on invertebrate paleontology. Part T. Echinodermata 2(2). Edited by R.C. Moore and C. Teichert. Geological Society of America and University of Kansas, Boulder and Lawrence, pp. T520-T564.

Northrop, S.A. 1939. Paleontology and stratigraphy of the Silurian rocks of the Port Daniel - Black Cape region, Gaspé. Geological Society of America, Special Paper, 21, 302 p. http://dx.doi.org/10.1130/spe21-p1

Nowlan, G. 1983. Early Silurian conodonts of eastern Canada. Fossils and Strata, 15, pp. 95-110.

Springer, F. 1928. Echinodermata. In A Geology of Anticosti Island by W.A. Twenhofel. Canadian Geological Survey, Memoir 154, pp. 137-140.

Stukalina, G.A. 1986. Zakonomernosti istoricheskogo rzvitiya krinoidei $\mathrm{v}$ rannemi srednem paleozoe SSSR [Laws of historical development of Crinoidea in the early and middle Paleozoic of the USSR]. Akademiya Nauk SSSR, Paleontological Institut Moskova, pp. 1-142. [In Russian; not seen.]

Stukalina, G.A. 1988. Studies in Paleozoic crinoid-columnals and -stems. Palaeontographica, A204, pp. 1-66.

Stukalina, G.A. 2000. [Paleozoic crinoids.] VSEGEI Press, St. Petersburg, 283 p. [In Russian.]

Ubaghs, G. 1978. Skeletal morphology of fossil crinoids. In Treatise on invertebrate paleontology. Part $\mathrm{T}$. Echinodermata 2(1). Edited by R.C. Moore and C. Teichert. Geological Society of America and University of Kansas Press, Boulder and Lawrence, pp. T58-T216.

Webster, G.D. 1974. Crinoid pluricolumnal noditaxis patterns. Journal of Paleontology, 48, pp. 1283-1288.

Webster, G.D. 1993. Bibliography and index of Paleozoic crinoids, 1986-1990. Geological Society of America Microform Publications, 25, $204 \mathrm{p}$.

Webster, G.D. 2016. Bibliography and index of Palaeozoic crinoids: Paleozoic crinoids, coronates, and hemistreptocrinoids, 1758-2012, viii+2694 p. URL <http://crinoids.azurewebsites.net/> April, 2016.

Wilson, R.A. and Kamo, S.L. 2012. The Salinic Orogeny in northern New Brunswick: geochronological constraints and implications for Silurian stratigraphic nomenclature. Canadian Journal of Earth Sciences, 49, pp. 222-238.

Wilson, R.A., Burden, E.T., Bertrand, R., Asselin, E., and McCracken, A.D. 2004. Stratigraphy and tectonosedimentary evolution of the Late Ordovician to Middle Devonian Gaspe Belt in northern New Brunswick: evidence from the Restigouche area. Canadian Journal of Earth Sciences, 41, pp. 527-551. http://dx.doi. org/10.1139/e04-011

Yeltysheva, R.S. 1955. [Class Crinoidea - sea lilies - stems of sea lilies.] In Field atlas of Ordovician and Silurian faunas of the Siberian Platform. Edited by O.I. Nikiforova. Leningrad, pp. 40-47. [In Russian.]

Yeltysheva, R.S. 1960. [The Ordovician and Silurian Crinoidea of the Siberian Platform.] Trudy Vsesoyuznogo Nauchno-Issledovatel'skogo Geologicheskogo Instituta (VESGEI), Leningrad, 3, pp. 1-39. [In Russian.]

Yeltysheva, R.S. 1979. Stebli paleozoiskikh morskikh liliy Pribaltiki (verkhny ordovik). [Stems of Paleozoic sea lilies of the Baltic area (Upper Ordovician).] Voprosy Paleontologii, 8, pp. 94-106. [In Russian; not seen.]

Yeltysheva, R.S. and Stukalina, G.A. 1963. Stebli ordovikskikh I nizhnesiluriyskikh krinoidey Tsentralnogo Taymyra, Novoy Zemli i Baygacha. [Stems of the Ordovician and Lower Silurian Crinoidea of the Central Taymyr, Novaya Zemlya, and Vaigach Island.] Uchenye zapiski Nauk Izvestiya Institut Geologii Arctic Paleontologiya i Biostratigrafiya, Izdatel'stvo, 2, pp. 23-62. [In Russian; not seen.]

Young G.A. and Noble, J.P.A., 1990. Silurian tabulate coral biostratigraphy and biofacies of northern New Brunswick and the southern Gaspé peninsula. Canadian Journal of Earth Sciences, 27, pp. 1143-1158. http://dx.doi. org/10.1139/e90-122

Editorial responsibility: Robert A. Fensome 